\title{
Cold Plasma Inactivation of Internalised Bacteria and Biofilms for Salmonella Enterica Serovar Typhimurium, Listeria Monocytogenes and Escherichia Coli
}

\author{
Dana Ziuzina \\ Technological University Dublin, dana.ziuzina@tudublin.ie \\ Lu Han \\ Technological University Dublin, lu.han@tudublin.ie \\ Patrick Cullen \\ Technological University Dublin, pj.cullen@tudublin.ie
}

See next page for additional authors

Follow this and additional works at: https://arrow.tudublin.ie/schfsehart

Part of the Food Microbiology Commons, and the Food Processing Commons

\begin{abstract}
Recommended Citation
Ziuzina, D., Han, L., Cullen, P. J., Bourke, P. (2015) Cold plasma inactivation of internalised bacteria and biofilms for Salmonella enterica serovar Typhimurium, Listeria monocytogenes and Escherichia coli, International Journal of Food Microbiology (2015), doi: 10.1016/j.ijfoodmicro.2015.05.019
\end{abstract}

This Article is brought to you for free and open access by the School of Food Science and Environmental Health at ARROW@TU Dublin. It has been accepted for inclusion in Articles by an authorized administrator of ARROW@TU

Dublin. For more information, please contact

arrow.admin@tudublin.ie, aisling.coyne@tudublin.ie, gerard.connolly@tudublin.ie.

Funder: European Community

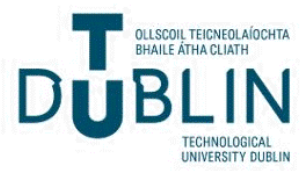




\section{Authors}

Dana Ziuzina, Lu Han, Patrick Cullen, and Paula Bourke

This article is available at ARROW@TU Dublin: https://arrow.tudublin.ie/schfsehart/155 


\section{Accepted Manuscript}

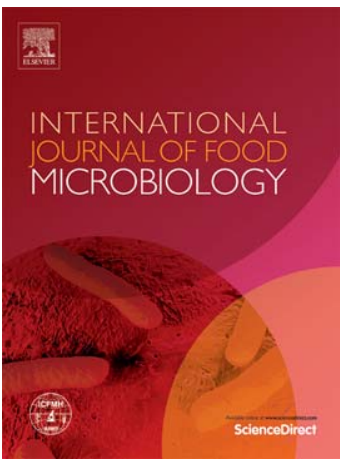

DOI:

S0168-1605(15)30017-9

Cold plasma inactivation of internalised bacteria and biofilms for Salmonella enterica serovar Typhimurium, Listeria monocytogenes and Escherichia coli

Dana Ziuzina, Lu Han, Patrick J. Cullen, Paula Bourke

DOI: $\quad$ doi: $10.1016 / j$.jijfoodmicro.2015.05.019

Reference: $\quad$ FOOD 6933

To appear in: $\quad$ International Journal of Food Microbiology

Received date: 20 January 2015

Revised date: $\quad 12$ May 2015

Accepted date: $\quad 27$ May 2015

Please cite this article as: Ziuzina, Dana, Han, Lu, Cullen, Patrick J., Bourke, Paula, Cold plasma inactivation of internalised bacteria and biofilms for Salmonella enterica serovar Typhimurium, Listeria monocytogenes and Escherichia coli, International Journal of Food Microbiology (2015), doi: 10.1016/j.ijfoodmicro.2015.05.019

This is a PDF file of an unedited manuscript that has been accepted for publication. As a service to our customers we are providing this early version of the manuscript. The manuscript will undergo copyediting, typesetting, and review of the resulting proof before it is published in its final form. Please note that during the production process errors may be discovered which could affect the content, and all legal disclaimers that apply to the journal pertain. 


\section{Cold plasma inactivation of internalised bacteria and biofilms for Salmonella enterica serovar Typhimurium, Listeria monocytogenes and Escherichia coli}

Dana Ziuzina $^{\mathrm{a}}$, Lu Han ${ }^{\mathrm{a}}$, Patrick J. Cullen ${ }^{\mathrm{b}}$, Paula Bourke ${ }^{\mathrm{a}}$

${ }^{a}$ Plasma Research Group, School of Food Science and Environmental Health, Dublin Institute of Technology, Dublin 1, Ireland.

${ }^{\mathrm{b}}$ School of Chemical Engineering, University of New South Wales, Sydney, Australia.

Corresponding author:

Dr. Paula Bourke

School of Food Science and Environmental Health, Dublin Institute of Technology, Dublin 1, Ireland

Tel: +35314027594

Fax: +3531878 8978

E-mail: paula.bourke@dit.ie

\section{Abstract}

Microbial biofilms and bacteria internalised in produce tissue may reduce the effectiveness of decontamination methods. In this study, the inactivation efficacy of in-package atmospheric cold plasma (ACP) afterglow was investigated against Salmonella Typhimurium, Listeria monocytogenes and Escherichia coli in the forms of planktonic cultures, biofilms formed on lettuce and associated bacteria internalised in lettuce tissue. Prepared lettuce broth (3\%) was inoculated with bacteria resulting in a final concentration of $\sim 7.0 \log _{10} \mathrm{CFU} / \mathrm{ml}$. For biofilm formation and internalisation, lettuce pieces $(5 \times 5 \mathrm{~cm})$ were dip-inoculated in bacterial suspension of $\sim 7.0 \log _{10} \mathrm{CFU} / \mathrm{ml}$ for $2 \mathrm{~h}$ and further incubated for 0,24 and $48 \mathrm{~h}$ at either $4^{\circ} \mathrm{C}$ or room temperature $\left(22^{\circ} \mathrm{C}\right)$ in combination with light/dark photoperiod or at $4^{\circ} \mathrm{C}$ under dark conditions. Inoculated samples were sealed inside a rigid polypropylene container and indirectly exposed (i.e. placed outside plasma discharge) to a high voltage $\left(80 \mathrm{kV}_{\mathrm{RMS}}\right)$ air ACP with subsequent storage for $24 \mathrm{~h}$ at $4^{\circ} \mathrm{C}$. ACP treatment for $30 \mathrm{~s}$ reduced planktonic populations of Salmonella, L. monocytogenes and E. coli suspended in lettuce broth to undetectable levels. Depending on storage conditions, bacterial type and age of biofilm, $300 \mathrm{~s}$ 
of treatment resulted in reduction of biofilm populations on lettuce by a maximum of $5 \log _{10}$ CFU/sample. Scanning electron and confocal laser microscopy pointed to the incidence of bacterial internalisation and biofilm formation, which influenced the inactivation efficacy of ACP. Measured intracellular reactive oxygen species (ROS) revealed that the presence of organic matter in the bacterial suspension might present a protective effect against the action of ROS on bacterial cells. This study demonstrated that high voltage in-package ACP could be a potential technology to overcome bacterial challenges associated with food produce. However, the existence of biofilms and internalised bacteria should be considered for further optimisation of ACP treatment parameters in order to achieve an effective control of the realistic challenges posed by foodborne pathogens.

Key words: Atmospheric cold plasma, Salmonella Typhimurium, Listeria monocytogenes and Escherichia coli, biofilms, internalisation.

\section{Introduction}

Foodborne human illnesses resulting from contaminated fresh produce have been widely reported throughout the world. In 2011, bacterial pathogens, including E. coli O157:H7, Salmonella spp. and Listeria monocytogenes, were considered to be the most important food safety issue for fresh produce, followed by foodborne viruses, pesticide residues and mycotoxins (Van Boxstael et al., 2013).

Microbial contamination can occur during any of the steps between the farm and consumer.

Post-harvest sources of contamination include human handling, harvesting equipment, transport containers, wild and domestic animals, insects, dust, rinse water, ice and transport vehicles (Buck et al., 2003). Additionally, the processing steps involving mechanical contact, immersion in water, and cutting or slicing of fresh produce, can result in enhanced microbial growth, potentially representing a major source of pathogenic contamination (Gil and 
Allende, 2012; Olaimat and Holley, 2012). It has been demonstrated that the highest levels of total aerobic bacteria, yeasts, Enterobacteriaceae were detected on processing equipment, such as cutters, peeling machines, etc. as well as on packaging surfaces (Lehto et al., 2011). During the last decades, it has become clear that human pathogens, including Salmonella spp., Listeria monocytogenes and E. coli, grow predominantly as biofilms on a variety of biotic and abiotic surfaces, rather than in planktonic form (Giaouris et al., 2014). Bacterial biofilms are broadly described as a microbially derived sessile community characterized by cells that are firmly attached to a substratum or to each other and are embedded in a matrix of extracellular polymeric substances (EPS) (Giaouris et al., 2014). Formation of bacterial biofilms on food, food contact surfaces, on food processing equipment and in potable water distribution systems contributes to food spoilage, cross-contamination of food products and spread of foodborne pathogens (Kim and Wei, 2012). Moreover, biofilms exhibit increased tolerance to antimicrobial agents. In the United States approximately $80 \%$ of persistent bacterial infections were found to be associated with biofilms (Srey et al., 2014). Another factor that could have a potential contribution to elevated resistance to antimicrobial agents is that bacterial pathogens can become internalized inside plant tissue. Bacterial internalization may occur through entering plant natural openings (e.g. hydathodes, stomata, lenticels) or physically damaged sites during processing and is dependent on time, temperature, light, pressure, produce surface characteristics and the native endophytic microbial community (O’Beirne et al., 2014; Gu et al., 2013a, b; Deering et al., 2012; Golberg et al., 2011; Kroupitski et al., 2009). Due to the various factors that can influence the microbiological quality of fresh produce, i.e. biofilm formation and cell internalization, implementation of effective decontamination steps within production chain are required in order to ensure microbiological safety of pre-packaged, ready to eat fruit and vegetables. 
Atmospheric cold plasma (ACP) technology is a relatively new approach aiming to improve microbiological safety in conjunction with maintenance of sensory attributes of the treated foods. Key process advantages of the approach include minimal water usage, low operating temperatures and low costs. To date, much research has been done towards investigation of the efficacy of plasma for eradication of bacterial biofilms (Traba et al., 2013; Alkawareek et al., 2012a, b; Maisch et al., 2012; Sun et al., 2012; Traba and Liang, 2011). However, there are limited reports on the use of ACP for elimination of internalised bacteria and bacterial biofilms associated with fresh produce. Apart from issues associated with conventional water mediated decontamination, it is likely that many of the features associated with minimal processing that impact on traditional washing decontamination, may also interact with the optimum application of ACP. Therefore, the main objectives of this study were to investigate inactivation effects of high voltage in-package dielectric barrier discharge cold atmospheric plasma (DBD ACP) against Salmonella enterica serovar Typhimurium, Listeria monocytogenes and Escherichia coli in model media, biofilms formed on lettuce and associated bacteria internalised in lettuce tissue. The effects of different time and temperature storage conditions on bacterial internalisation and biofilm formation on lettuce and any possible effects on ACP antimicrobial efficacy were evaluated utilising different techniques, including colony count assay, DCFH-DA (2',7'-Dichlorofluorescin diacetate) assay for measurement of intracellular reactive oxygen species (ROS), scanning electron microscopy (SEM) and confocal laser scanning electron microscopy (CLSM).

\section{Methodology}

\subsection{Bacterial strains and inocula preparation}

Three bacterial strains were used in this study. Salmonella enterica serovar Typhimurium ATCC 14028 and Listeria monocytogenes NCTC 11994 were obtained from the microbiology stock culture of the School of Food Science and Environmental Health of the 
Dublin Institute of Technology. Ampicillin resistant E. coli BL21 was obtained from the microbiology stock culture of the Focas Research Institute of the Dublin Institute of Technology. Ampicillin resistant E. coli XL10 expressing green fluorescent protein (GFP) was obtained from the microbiology stock culture of the School of Biochemistry and Immunology, Trinity Biomedical Sciences Institute, Trinity College Dublin, and was used in order to visualise bacteria within plant tissue. Stock cultures were maintained at $-70^{\circ} \mathrm{C}$ in the form of protective beads (Technical Services Consultants Ltd, UK). One protective bead of Salmonella Typhimurium and L. monocytogenes was streaked onto separate tryptic soy agar (TSA, ScharlauChemie, Spain) and E. coli strains were streaked onto TSA supplemented with ampicillin (100 mg/L) (Sigma Aldridge, Ireland). The plates were incubated at $37^{\circ} \mathrm{C}$ for $24 \mathrm{~h}$ and further maintained at $4^{\circ} \mathrm{C}$. A single isolated colony of each culture was inoculated in tryptic soy broth without glucose (TSB, ScharlauChemie, Spain) and incubated at $37^{\circ} \mathrm{C}$ for $18 \mathrm{~h}$ until the stationary growth phase was reached. TSB supplemented with ampicillin was used for E. coli strains. After incubation, the cells were harvested by centrifugation at 10,000 rpm for $10 \mathrm{~min}$, washed twice in sterile phosphate buffered solution (PBS, Oxoid LTD, UK) and finally resuspended in PBS.

To prepare planktonic populations, bacterial cell density was determined by measuring absorbance at $550 \mathrm{~nm}$ using the McFarland standard (BioMérieux, Marcy -l'Etoile, France) to allow a working inoculum corresponding to $7.0 \log _{10} \mathrm{CFU} / \mathrm{ml}$ to be prepared.

For lettuce inoculation studies, after washing, each bacterial PBS suspension (10 ml) was transferred into $1 \mathrm{~L}$ of sterile deionised water to achieve final cell concentrations of approximately $7.0 \log _{10} \mathrm{CFU} / \mathrm{ml}$, which was further used as a working inoculum. The concentration of inoculum was confirmed by plating appropriate dilutions on TSA, followed by incubation at $37^{\circ} \mathrm{C}$ for $24 \mathrm{~h}$ for Salmonella and E. coli and $48 \mathrm{~h}$ for L. monocytogenes.

\subsection{Preparation of produce}


Fresh iceberg lettuce (Class I, Origin: Spain) was purchased from the local supermarket on the day of the experiment and stored at $4{ }^{\circ} \mathrm{C}$ until use. The outer lettuce leaves were removed and intact inner leaves were selected for the experiment. The leaves were aseptically cut into $5 \times 5 \mathrm{~cm}$ pieces, each of $1.7-2.4 \mathrm{~g}$, using a sterile scalpel and immediately used in the experiments.

\subsection{Preparation of lettuce broth}

Lettuce broth (LB) was prepared as for the method described by Shen et al. (2012) with minor modifications. Lettuce juice, extracted by processing of iceberg lettuce in a commercial household juice maker (model JE3 1/03, Breville, UK), was centrifuged (10,000 rpm for $10 \mathrm{~min}$ at $4^{\circ} \mathrm{C}$ ) twice to remove coarse particles. Supernatants were passed through paper filters (Whatman, England, UK), then through $0.45 \mu \mathrm{m}$ filters (Millipore, Ireland), sterilized through $0.2 \mu \mathrm{m}$ membrane filters (Millipore, Ireland) and then diluted in sterile distilled water to make 3\% LB (pH 6.3).

\subsection{Inoculation procedure}

Prepared LB (3\%) was inoculated with an appropriate amount of bacterial suspension corresponding to a final cell density of $\sim 7.0 \log _{10} \mathrm{CFU} / \mathrm{ml}$.

The lettuce inoculation procedure was conducted as described by Kroupitski et al. (2009) with minor modifications. Lettuce pieces were submerged in a sterile beaker containing 300 $\mathrm{ml}$ of bacterial suspension in the laminar flow cabinet. Following incubation for $2 \mathrm{~h}$, the samples were rinsed with sterile deionised water in a separate beaker in order to remove unattached bacteria, drained and dried on sterile aluminium foil in the laminar flow cabinet for $15 \mathrm{~min}$ from both sides. Following air-drying, the samples were transferred into sterile petri dishes and incubated for 0,24 and $48 \mathrm{~h}$ at either room temperature $\left(\sim 22^{\circ} \mathrm{C}\right)$ or $4^{\circ} \mathrm{C}$ in 
light/dark photoperiod (day/night regime). In a separate experiment, to assess the influence of light on microbial attachment, the samples were incubated for $24 \mathrm{~h}$ and $48 \mathrm{~h}$ at $4{ }^{\circ} \mathrm{C}$ in the dark.

For microscopic observations, 1 x $1 \mathrm{~cm}$ pieces excised from the lettuce leaf were spotinoculated on both sides using bacterial culture grown overnight and washed in PBS (100 $\mu 1)$. For SEM analysis lettuce pieces were inoculated with Salmonella Typhimurium and further incubated for $48 \mathrm{~h}$ at room temperature and the light/dark photoperiod. For CLSM analysis lettuce samples inoculated with E. coli XL10 (GFP) were incubated for $24 \mathrm{~h}$ at either room temperature or $4^{\circ} \mathrm{C}$ in the light/dark photoperiod and $4^{\circ} \mathrm{C}$ under dark conditions.

\subsection{Experimental design}

The ACP system utilised was a dielectric barrier discharge system previously described in Ziuzina et al. (2013). For each experiment two individually grown overnight cultures were used to inoculate two separately prepared LB. Prior ACP treatments, inoculated LB was dispensed into a 96 well microtiter plate $(100 \mu$ l per each well).

Planktonic populations (in 96 well plate) and bacteria inoculated on lettuce were tested in separate containers. Separate containers were also used for 1) lettuce inoculated with different bacteria; 2) lettuce (inoculated with corresponded bacteria) incubated for different period of time: 0,24 or $48 \mathrm{~h} ; 3$ ) lettuce (inoculated with corresponded bacteria) subjected to storage at different temperature/light storage conditions: room temperature in light/dark photoperiod, $4^{\circ} \mathrm{C}$ in light/dark photoperiod and at $4^{\circ} \mathrm{C}$ in the dark stored for either 24 or $48 \mathrm{~h}$. Inoculated with identical bacterial species lettuce samples (two for each experiment) or microtiter plate containing inoculated LB were aseptically transferred into the corner of the container so as to expose the samples to indirect (afterglow) ACP discharge as described in Ziuzina et al. (2014). 
After sample loading, each container was sealed within a high barrier polypropylene film (Cryovac, B2630, USA) and placed between the aluminium electrodes of the transformer. The inoculated LB and lettuce samples were treated with $80 \mathrm{kV}_{\mathrm{RMS}}$ for $30 \mathrm{~s}$ and $300 \mathrm{~s}$, respectively, in air at atmospheric pressure. All samples were subjected to a post-treatment storage time of $24 \mathrm{~h}$ at $4^{\circ} \mathrm{C}$. In order to evaluate any possible effect of storage on the bacterial growth, inoculated and stored at corresponding conditions control samples were subjected to storage under similar conditions, i.e. $24 \mathrm{~h}$ at $4^{\circ} \mathrm{C}$. All experiments were performed in duplicate and replicated at least twice to ensure reproducibility of the experimental data and are reported as $\log _{10} \mathrm{CFU} / \mathrm{ml}$ for bacterial reductions in $\mathrm{LB}$ or $\log _{10} \mathrm{CFU} / \mathrm{sample}$ for bacterial reductions on lettuce, where each sample weighed an average of $1.9 \pm 0.3 \mathrm{~g}$.

\subsection{Microbiological analysis}

For microbiological analysis, inoculated untreated control lettuce samples incubated at the conditions described in section 2.4 (to estimate initial bacterial planktonic or biofilm population), inoculated untreated controls stored for $24 \mathrm{~h}$ of post treatment storage time (to estimate the effect of $24 \mathrm{~h}$ storage on microbial growth), and inoculated ACP treated and stored for $24 \mathrm{~h}$ at $4{ }^{\circ} \mathrm{C}$ samples were analysed. Lettuce samples were aseptically transferred into separate sterile stomacher bags (BA6041, Seward LTD, UK) with $10 \mathrm{ml}$ of sterile maximum recovery diluent (MRD, ScharlauChemie, Spain) and homogenised for 2 min in the stomacher (Model: BA6020, England). The resulting suspension was serially diluted in MRD. The surviving Salmonella and L. monocytogenes populations were determined by agar overlay method (Mahmoud, 2010). Briefly, aliquots of an appropriate dilution were surface plated on TSA, incubated for 2-4 h, and overlayed with the appropriate selective media Xylose Lysine Deoxycholate agar (XLD, ScharlauChemie, Spain) for Salmonella, and polymyxin-acriflavine-LiCl-ceftazidime-aesculin-mannitol (PALCAM, ScharlauChemie, Spain) supplemented with PALCAM Listeria Selective Supplement (Oxoid LTD, England) 
for L. monocytogenes. TSA supplemented with ampicillin was used for E. coli. Plates were then incubated for $24-48 \mathrm{~h}$ at $37^{\circ} \mathrm{C}$. Populations of planktonic cells were estimated by plating appropriate dilutions on non-selective media TSA. The limit of detection for bacterial recovery was $1.0 \log _{10} \mathrm{CFU} / \mathrm{sample}$ or $\log _{10} \mathrm{CFU} / \mathrm{ml}$.

\subsection{Confocal Laser Scanning Microscopy (CLSM)}

In order to study the effect of different temperature and light storage conditions on the bacterial proliferation on lettuce, CLSM analysis was conducted utilising GFP expressing $E$. coli XL10. Inoculated untreated samples were analysed using Leica confocal microscope (Leica, Model: TCS SP8 STED) with excitation/emission 488/500-520 nm laser lines and 20x lenses and at least 10 randomly chosen microscopic fields were examined for each sample incubated at each storage condition studied. The images were obtained using IMARIS image analysis software (Bitplane, Inc.).

\subsection{Scanning Electron Microscopy (SEM)}

The effect of ACP treatment on Salmonella $48 \mathrm{~h}$ bacterial biofilms formed on lettuce at $4^{\circ} \mathrm{C}$ in light/dark photoperiod was observed using SEM. ACP treated or untreated samples were prepared as described by Srey et al. (2014) with minor modifications. The cells were fixed in ice-cold $2.5 \%$ glutaraldehyde in $0.05 \mathrm{M}$ sodium cacodylate buffer (pH7.4) (SCB) for $2 \mathrm{~h}$. The cells were washed with the same buffer three times and fixed in $1 \%$ osmium tetroxide for $2 \mathrm{~h}$ at $4{ }^{\circ} \mathrm{C}$. After $2 \mathrm{~h}$ of fixation, bacterial cells were washed with SCB followed by three washes with distilled water. The samples were dehydrated using increasing concentrations of ethanol $(30 \%, 50 \%, 70 \%, 80 \%, 95 \%$ and $99.5 \%)$ following by dehydration with series of $33 \%, 50 \%$, $66 \%$, and $100 \%$ of hexamethyldisilazane (Sigma Aldrich, Ireland). In order to prevent surface charging by the electron beam, the samples were sputter-coated with gold particles using 
Emitech K575X Sputter Coating Unit resulting in a coating of $10 \mathrm{~nm}$ after $30 \mathrm{~s}$. The samples were examined visually using a FEI Quanta 3D FEG Dual Beam SEM (FEI Ltd, Hillsboro, USA) at $5 \mathrm{kV}$.

\subsection{Intracellular reactive oxygen species (ROS) measurements}

In order to examine if organic matter present in contaminated suspensions has any effect on generation of ROS within the bacterial cells, 2',7'-dichlorofluorescin diacetate (DCFH-DA) assay (Sigma Aldrige, Ireland) was utilised. DCFH-DA is a non-fluorescent cellular probe, which turns to a highly fluorescent 2', 7'-dichlorofluorescein (DCF) upon oxidation by ROS and can be directly correlated to ROS concentration. To detect intracellular ROS, $L$. monocytogenes and E. coli BL21 (Gram ${ }^{+}$and $\mathrm{Gram}^{-}$, respectively) suspended in PBS and lettuce broth (3\%) with final cell concentration of $\sim 7.0 \log _{10} \mathrm{CFU} / \mathrm{ml}$ were subjected to $30 \mathrm{~s}$ of ACP treatment and $0 \mathrm{~h}$ of post treatment storage. Immediately after treatment cell suspensions were incubated with DCFH-DA at a final concentration of $5 \mu \mathrm{M}$ in PBS for 15 $\min$ at $37^{\circ} \mathrm{C}$. Aliquots of each sample $(200 \mu \mathrm{l})$ were transferred to 96 well fluorescence microplate wells (Fisher Scientific, UK) and measured by Synergy ${ }^{\mathrm{TM}}$ HT Multi-Mode Microplate Reader (BioTek Instruments Inc.) at excitation and emission wavelengths of 485 and $525 \mathrm{~nm}$. Due to the high autofluorescence of LB, fluorescence values obtained for treated LB bacterial suspensions were corrected by subtracting the means of fluorescence of a blank (uninoculated) LB. Experiments were carried out in duplicate and repeated at least twice.

\subsection{Ozone measurements}

In this work the treatment time utilised for the planktonic populations was $30 \mathrm{~s}$ and for bacterial populations attached on lettuce surface was $300 \mathrm{~s}$. Therefore ozone concentration was measured at these times. Ozone measurements were taken with packages containing 
either inoculated lettuce samples or 96 well plates containing inoculated lettuce broth using Gastec ozone detector tubes (Product \#18M, Gastec Corporation, Japan) as an indicator of the metastable ROS generated by ACP. Measurements were taken immediately after plasma treatment and after $24 \mathrm{~h}$ of post treatment storage. For a complete diagnostic of the ROS and reactive nitrogen species (RNS) generated within the package the reader is directed to Moiseev et al. (2014).

\subsection{Statistical Analysis}

Statistical analysis was performed using IBM SPSS statistics 22 Software (SPSS Inc., Chicago, USA). The surviving population of Salmonella, L. monocytogenes and E. coli following ACP treatment were subjected to Mixed Design Analysis Of Variance (ANOVA) (Repeated measures with a between subject factor). Means were compared according to the method of Fisher's Least Significant Difference-LSD at the 0.05 level. Adjustment for multiple comparisons was made using Bonferroni method. Average bacterial populations recovered from lettuce samples were compared within the 'time' subgroups: inoculated untreated controls and inoculated and stored for 24 or $48 \mathrm{~h}$ ACP treated samples; and between the 'storage' groups, i.e. samples inoculated and stored at different temperature/light regimes: room temperature and light/dark, $4^{\circ} \mathrm{C}$ and light/dark and $4{ }^{\circ} \mathrm{C}$ and dark either for 24 or $48 \mathrm{~h}$ followed by ACP treatment, and interactions between the 'time' group and 'storage' group were tested. The mean value of the untreated control samples represent an average of 0 $\mathrm{h}, 24 \mathrm{~h}$ and $48 \mathrm{~h}$ of untreated controls. The average reductions in populations of each bacteria type (Salmonella, L. monocytogenes, E. coli) have not been compared between each other.

\section{Results}

\subsection{Effect of ACP on planktonic bacterial populations in lettuce broth.}


Surviving populations of Salmonella, L. monocytogenes and E. coli suspended in lettuce broth $3 \%$ are depicted in Fig. 1. Average initial cell concentration in the media was $6.8 \pm 0.1$, $7.2 \pm 0.1$ and $6.4 \pm 0.2 \log _{10} \mathrm{CFU} / \mathrm{ml}$ for Salmonella, L. monocytogenes and E. coli, respectively. Within $30 \mathrm{~s}$ of treatment and $24 \mathrm{~h}$ of post treatment storage at $4^{\circ} \mathrm{C}$ populations of all bacteria tested were reduced to undetectable levels (limit of detection $1.0 \log _{10}$ CFU/sample).

\subsection{Effect of ACP on bacterial populations inoculated on lettuce}

The antimicrobial efficacy of ACP against bacteria inoculated on lettuce is presented in Fig. 2. Deep-inoculation of lettuce in Salmonella, L. monocytogenes and E. coli cell suspensions for $2 \mathrm{~h}$ resulted in average attached populations of $6.5 \pm 0.4,6.0 \pm 0.2$ and $5.6 \pm 0.1 \log _{10}$ CFU/sample, respectively. ACP treatment time of 300 s reduced Salmonella and $L$. monocytogenes counts by $2.4 \pm 0.9$ and $2.3 \pm 1.4 \log _{10} \mathrm{CFU} /$ sample. Higher inactivation levels were observed for $E$. coli, where treatment resulted in reduction of bacterial numbers by 3.3 $\pm 1.6 \log _{10} \mathrm{CFU} / \mathrm{sample}$.

\subsection{Effect of ACP on internalised bacteria and bacterial biofilms formed on lettuce at room temperature and at $4^{\circ} \mathrm{C}$ in light/dark photoperiod}

Average initial populations of Salmonella, L. monocytogenes and E. coli $24 \mathrm{~h}$ and $48 \mathrm{~h}$ biofilms grown at room temperature in light/dark photoperiod and corresponding reductions due to ACP treatment are presented in Fig. 3. After $300 \mathrm{~s}$ of treatment, the concentration of cells in $24 \mathrm{~h}$ biofilms of each bacteria tested were reduced significantly $(\mathrm{p} \leq 0.05)$ compared with an average of the untreated ( 0 h, $24 \mathrm{~h}$ and $48 \mathrm{~h})$ controls. Thus, Salmonella, $L$. monocytogenes and E. coli decreased by $4.0 \pm 1.3,3.5 \pm 0.8$ and $3.0 \pm 2.0 \log _{10} \mathrm{CFU} /$ sample from $7.8 \pm 0.2,6.8 \pm 0.4$ and $6.2 \pm 0.8 \log _{10} \mathrm{CFU} /$ sample initially present on lettuce, 
respectively. Increased resistance to ACP treatment was observed in the case of $48 \mathrm{~h}$ biofilms with $1.8 \pm 0.3 \log$ units reduction achieved for Salmonella and $1.6 \pm 0.5 \log$ for $L$. monocytogenes biofilms. Similar reduction levels of $1.6 \pm 0.9 \log _{10} \mathrm{CFU} / \mathrm{sample}$ were observed for E. coli $48 \mathrm{~h}$ biofilms; however, these reductions were statistically insignificant as compared to the untreated controls.

Fig. 4 represents surviving populations of Salmonella, L. monocytogenes and E. coli for $24 \mathrm{~h}$ and $48 \mathrm{~h}$ biofilms developed at $4{ }^{\circ} \mathrm{C}$ in light/dark photoperiod. ACP treatment for $300 \mathrm{~s}$ significantly reduced Salmonella $24 \mathrm{~h}$ and $48 \mathrm{~h}$ biofilms $(\mathrm{p}<0.05)$, which decreased by 1.6 \pm 0.1 and $3.3 \pm 1.2 \log _{10} \mathrm{CFU} / \mathrm{sample}$, respectively, from the initial $5.6 \pm 0.3 \log _{10} \mathrm{CFU} / \mathrm{sample}$ obtained as an average of the untreated $0 \mathrm{~h}, 24 \mathrm{~h}$ and $48 \mathrm{~h}$ controls. No significant reduction in the levels of L. monocytogenes and E. coli $24 \mathrm{~h}$ biofilms was observed after the treatment. However, populations of $48 \mathrm{~h} \mathrm{~L}$. monocytogenes and E. coli biofilms significantly decreased by $3.4 \pm 2.0$ and $3.3 \pm 1.4 \log _{10} \mathrm{CFU} /$ sample $(\mathrm{p}<0.05)$ when compared to the untreated controls of $6.5 \pm 0.5$ and $5.3 \pm 1.6 \log _{10} \mathrm{CFU} /$ sample, respectively. Overall, similar antimicrobial effects of ACP treatment were noted when reduction levels of $48 \mathrm{~h}$ biofilms of each pathogen are compared ( 3.3 log units).

\subsection{Effect of ACP on internalised bacteria and bacterial biofilms formed on lettuce at $4^{\circ} \mathrm{C}$ in dark}

Relatively higher biofilm inactivation levels due to ACP treatment were observed when postinoculation storage conditions for lettuce of $4^{\circ} \mathrm{C}$ in dark were utilised for biofilm development (Fig. 5). Thus, treatment for 300 s reduced populations of Salmonella, $L$. monocytogenes and E. coli 24 h biofilms by $4.1 \pm 1.0,3.8 \pm 1.5$ and $3.0 \pm 2.6 \log _{10}$ CFU/sample from initial $6.7 \pm 0.1,5.9 \pm 0.2$ and $5.2 \pm 0.7 \log _{10}$ CFU/sample, respectively. Although there was no statistical difference between reductions in population of 24 and $48 \mathrm{~h}$ 
biofilms observed, the maximum biofilm inhibition was achieved for $48 \mathrm{~h}$ biofilms, where counts were further decreased by $5.1 \pm 1.8,4.5 \pm 1.0$ and $4.0 \pm 1.5 \log _{10}$ CFU/sample.

A mixed design ANOVA was conducted to assess the impact of three different storage condition groups, i.e. 'room temperature and light/dark', ' $4{ }^{\circ} \mathrm{C}$ and light/dark' and ' $4{ }^{\circ} \mathrm{C}$ and dark' on bacterial susceptibility towards ACP treatment across three time groups, i.e. untreated, stored for $24 \mathrm{~h} /$ treated and stored for $48 \mathrm{~h} /$ treated samples for each type of bacteria studied. For Salmonella, there were significant differences in cell numbers found between the time groups, $\mathrm{F}(2,18)=54.7 ; \mathrm{p}<0.05$ and between the storage groups, $\mathrm{F}(2,9)=17.9 ; \mathrm{p}<0.05$. Specifically, all three storage groups significantly differed between each other at untreated control time, while at $48 \mathrm{~h}$ the 'room temperature and light/dark' significantly differed from ' $4{ }^{\circ} \mathrm{C}$ and light/dark' and ' $4{ }^{\circ} \mathrm{C}$ and dark' groups $(\mathrm{p}<0.05)$. The tests between subject effects demonstrated substantial interaction between the time and storage groups, $\mathrm{F}(4,18)=7.9$; $\mathrm{p}<0.05$. Similarly, for L. monocytogenes significant differences in cell numbers were found between the storage groups $\mathrm{F}(2,9)=12.8 ; \mathrm{p}<0.05$, specifically between the groups of 'room temperature and light/dark' and ' $4{ }^{\circ} \mathrm{C}$ and light/dark' or ' $4{ }^{\circ} \mathrm{C}$ and dark' groups and between the 'room temperature and light/dark' and ' $4{ }^{\circ} \mathrm{C}$ and dark' group at the time group of 24 and $48 \mathrm{~h}$, respectively. The main effects comparing the three time groups was also found to be significant $\mathrm{F}(2,18)=31.8 ; \mathrm{p}<0.05$ and significant interaction was again observed between time and storage groups $F(4,18)=7.7 ; p<0.05$. There was no significant interaction found between the time and storage groups in the case of $E$. coli, $\mathrm{F}(4,18)=2.3 ; \mathrm{p}=0.094$. However, the main effect of the three time groups across the three storage conditions as well as between the storage groups at each time point tested was found to be significant $\mathrm{P}(2,18)=17.3 ; \mathrm{p}<0.05$ and $\mathrm{P}(2,9)=6.5 ; \mathrm{p}<0.05$, respectively.

\subsection{Confocal Laser Scanning microscopy (CLSM)}


In order to examine if storage conditions, such as temperature and light, had any effects on localization of cells within the plant tissue and possible effects on ACP treatment, CLSM analysis was conducted using GFP-tagged E. coli inoculated on lettuce. CLSM images (Fig. 6) illustrate the distribution of fluorescent E. coli cells on lettuce following $24 \mathrm{~h}$ incubation at different storage conditions. Fig. $6 a$ and 6 b represent localization of cells on the lettuce as a result of storage at room temperature and $4{ }^{\circ} \mathrm{C}$ in the light/dark photoperiod, respectively. Both conditions resulted in firm cell attachment on the surface and cell internalization in lettuce stomata. In contrast, for inoculated lettuce samples stored at $4^{\circ} \mathrm{C}$ in the dark (Fig. 6c), no incidence of internalisation was noted: cells were mostly attached to the lettuce surface and near stomatal areas.

\subsection{Scanning Electron Microscopy (SEM)}

SEM analysis was utilised in order to observe the effects of high voltage ACP treatment on bacterial biofilms and internalised bacteria associated with lettuce (Fig. 7). SEM micrographs (Fig. 7a) show localization of untreated Salmonella cells in a $48 \mathrm{~h}$ biofilm formed on lettuce at room temperature for the light/dark photoperiod. The untreated lettuce bacteria were found to be healthy individual cells, in the form of small clusters and biofilm aggregates attached on the lettuce surface, near the stomata and internalised inside the stomata (black arrows). The majority of the stomata on the control samples subjected to imaging were highly colonized with bacterial cells; however, some of the stomata were colonized to a lesser degree or found to be uncolonised. Images of ACP treated samples (Fig. 7b) indicated the presence of cell debris around the stomata (red arrows). It is more likely that the action of ACP caused bacterial cell ruptures, thus irreversibly changing the original morphological characteristics of the cells. However, among the dead cell fragments found on the surface of the lettuce, intact cells remained inside stomata post treatment (black arrows). 


\subsection{ROS measurements}

Concentrations of ROS generated after 30 s of indirect ACP treatment inside $L$. monocytogenes and E. coli cells suspended either in PBS or in LB (3\%) are presented in Fig 8. Thus, an average concentration of ROS generated inside either L. monocytogenes or E. coli cells suspended in PBS was twice as high as the ROS concentration recorded for cells suspended in LB. However, relatively lower levels of intracellular ROS were observed for Gram-negative E. coli suspended in both PBS and LB when compared to the Gram-positive L. monocytogenes.

\subsection{Ozone measurements}

Indirect ACP treatment time of $300 \mathrm{~s}$ resulted in an average concentration of ozone generated inside the sealed package containing inoculated lettuce samples of $4420 \pm 240 \mathrm{ppm}$. Average ozone concentration recorded after 30 s of treatment of inoculated LB in 96-well plate reached $2220 \pm 130 \mathrm{ppm}$.

\section{Discussion}

Recent health associated outbreaks, which have been linked to the consumption of fresh produce, demands research for more efficient decontamination techniques since current sanitation procedures show limited efficacy against bacterial pathogens attached to plant surface, internalized or in the form of biofilms (Olaimat and Holley, 2012; Olmez and Temur, 2010; Warning and Data, 2013). To date, among the various physical and chemical food decontamination techniques evaluated, ACP demonstrated high efficiency for the reduction of bacterial contaminants from the surface of fresh produce (Baier et al., 2014; Fernandez et al., 2013; Lacombe et al., 2015; Misra et al., 2014; Ziuzina et al., 2014). 
In this study, antimicrobial efficacy of in-package high voltage indirect ACP treatment was examined against a range of microorganisms commonly implicated in foodborne associated human infections; Salmonella, L. monocytogenes and E. coli monocultures in their planktonic form, in the form of biofilms and associated bacteria internalised in produce. Generally, indirect high voltage ACP treatment in conjunction with $24 \mathrm{~h}$ of post treatment storage time was very effective against planktonic populations of the three bacteria tested. High concentrations of bacterial cells ( 7.0 log units) were reduced to undetectable levels within $30 \mathrm{~s}$ of treatment. This is consistent with previous reports, which demonstrated $>5 \mathrm{log}$ reduction of planktonic bacterial populations achieved within less than $60 \mathrm{~s}$ of plasma treatment (Han et al., 2014; Jahid et al., 2015; Joshi et al., 2011; Kvam et al., 2012; Ziuzina et al., 2013). However, in the current work, when challenge microorganisms were inoculated on produce, an extended treatment time (300 s) was necessary in order to achieve significant reductions of the bacterial populations. Bacterial pathogens can rapidly and irreversibly attach on different plant commodities and persist for long periods of time; within $30 \mathrm{~s}$ of exposure, $30 \%$ of Salmonella inoculum was firmly attached to green papers slices (Solomon and Sharma 2009). Warning and Datta (2013) described that plant cuts, lenticels, trichomes, locations around the yeins and stomata are the preferential places for bacterial cell attachment. Jahid et al. (2014a) visualised bacteria associated with the stomatal wall, as well as inside the stomata. Furthermore, Gu et al. (3013b) reported that following leaf colonization bacteria could enter tomato leaves through hydathodes (plant water pores), resulting in the internal translocation of the bacteria inside plants. In the current work, it can be assumed that during $2 \mathrm{~h}$ of produce dip-inoculation in either Salmonella, L. monocytogenes or E. coli cells suspension, bacteria were strongly attached and possibly penetrated inside natural openings and indentations of lettuce leaves, which in turn considerably reduced the antimicrobial efficacy of the treatment. Similar effects was observed by Jahid et al. (2014a), where $15 \mathrm{~s}$ of 
ACP treatment inactivated planktonic populations of Aeromonas hydrophila by $>5 \log$, but 5 min of treatment was necessary to significantly reduce bacterial biofilm populations associated with lettuce. Similarly, ultraviolet $C$ irradiation fluency of $35 \mathrm{~mJ} / \mathrm{cm}^{2}$ was required to achieve a $5.0 \log \mathrm{CFU} / \mathrm{mL}$ reduction in planktonic populations, while $360 \mathrm{~mJ} / \mathrm{cm}^{2}$ was required to reduce bacteria cell number by $\sim 2.0 \log _{10} \mathrm{CFU} / \mathrm{cm}^{2}$ on lettuce (Jahid et al., 2014b).

In order to preserve the quality and assure microbiological safety, fresh produce are processed and stored at low temperatures, below $5^{\circ} \mathrm{C}$ (Heard, 2002; Olaimat and Holley, 2012). However, real temperatures during produce distribution from field to the retail store may vary largely (Koseki and Isobe, 2005) and even a slight increase in temperature (from 4 to $10^{\circ} \mathrm{C}$ ) can adversely affect quality characteristics of the produce (Bett-Garber et al., 2011). Moreover, fluctuations in the temperature, humidity and light intensity throughout distribution may also influence bacterial state and localization of bacteria on the produce (Golberg et al., 2011). Higher temperatures and higher light intensity may induce bacterial attachment, biofilm formation and internalisation of bacterial cells in plants (Kroupitski et al., 2009; Takeuchi et al., 2001). Therefore, because consistent storage of fresh produce at the recommended temperatures of $\sim 5^{\circ} \mathrm{C}$ is difficult to maintain throughout distribution (Koseki and Isobe, 2005), in this work, the effects of different storage temperatures $\left(4^{\circ} \mathrm{C}\right.$ and room temperature) in combination with different light regimes and storage times on bacterial proliferation, biofilm formation and susceptibility to ACP treatment were evaluated. The results of this study demonstrated that high voltage ACP treatment for $300 \mathrm{~s}$ was capable of reducing bacterial populations in $24 \mathrm{~h}$ biofilms grown at room temperature in the light/dark photoperiod by up to 4.0 log units. Although there was no significant difference between bacterial populations of $24 \mathrm{~h}$ and $48 \mathrm{~h}$ untreated controls, $48 \mathrm{~h}$ biofilms were more resistant to treatment by comparison with $24 \mathrm{~h}$ biofilms. Increased resistance of older biofilms could be 
due to the higher proportions of extracellular polymeric substances (EPS), produced by bacteria with longer storage durations (Shen et al., 2011; Traba and Liang, 2011). Similarly, Belessi et al. (2011) demonstrated that, despite a low incubation temperature of $4^{\circ} \mathrm{C}$, resistance of Listeria biofilms to chemical treatments increased with increasing incubation time. In contrast, in the current study, different inactivation patterns were observed for both $24 \mathrm{~h}$ and $48 \mathrm{~h}$ biofilms grown at $4{ }^{\circ} \mathrm{C}$ and similar light conditions, where $24 \mathrm{~h}$ biofilms of all three bacteria studied were more tolerant to ACP treatment than $48 \mathrm{~h}$ biofilms, when results are compared with reductions achieved for biofilms grown at room temperature (Figures 3 and 4). The reason for these unexpected results is unclear, but, one possible explanation could be that microorganisms encountered stress during leaf inoculation caused by the temperature change from room temperature to $4^{\circ} \mathrm{C}$, which was used for biofilm formation. It is known that when exposed to a mild stress, bacteria may adapt by developing resistance to greater amounts of that stress as well as cross-protection to other stresses (Beales, 2004). In food production environments microorganisms undergo a variety of stresses including extreme temperatures, which can have a significant effect on bacterial survival during food processing thus impacting the efficacy of decontamination treatments (Delaquis and Bach, 2012). For example, Al-Nabulsi et al. (2015) demonstrated an increased resistance of L. monocytogenes to antibiotic treatment when cells were exposed to temperature decreased to $10^{\circ} \mathrm{C}$. In this study, the stress encountered from the first $24 \mathrm{~h}$ storage cycle in the cold environment could lead to the increased resistance to ACP treatment. Cells embedded in the $48 \mathrm{~h}$ biofilms could possibly adapt to the low temperature and resume expression of non-cold inducible proteins (Barria et al., 2013), which could explain higher reduction levels of bacterial populations in $48 \mathrm{~h}$ biofilms achieved after treatment. However, further investigation of the bacterial adaptation to change in the environmental conditions and the corresponding bacterial response to ACP treatment may provide important information and help in future 
optimisation of treatment critical control parameters in order to achieve the maximal efficacy of ACP for decontamination of fresh produce.

In addition to the low temperature regime, light is considered as one of the most important factors responsible for produce quality maintenance throughout distribution and it has been reported that light exposure stimulates plant stomata opening (Martinez-Sanchez et al., 2011). In the current work, regardless of the low incubation temperature $\left(4^{\circ} \mathrm{C}\right)$ and bacterial type, higher inactivation levels were achieved for both $24 \mathrm{~h}$ and $48 \mathrm{~h}$ biofilms when developed on lettuce under dark conditions. Martinez-Sanchez et al. (2011), who examined surface of Romaine lettuce by using SEM, found that approximately $75 \%$ of lettuce stomata were closed due to storage in darkness, whereas a similar percentage of stomata remained opened when leaves were exposed to light. Moreover, Kroupitski et al. (2009) linked the increase in light intensity with higher internalisation rates of bacterial cells inside the lettuce leaf tissue. In this study, storage of inoculated lettuce in a dark environment probably induced stomata closure and where ACP generated reactive species probably acted directly on bacterial cells residing on the lettuce surface. This observation was supported by CLSM, which demonstrated an apparent difference in the localisation of bacterial cells when lettuce was exposed to different light regimes rather than different temperature regimes. In the dark, bacterial cells were located mostly on the surface of lettuce or near stomatal cavities, whereas light/dark conditions in combination with either refrigerated or room temperature storage resulted in penetration of cells within the lettuce stomata. Takeuchi et al. (2001) also reported higher internalisation levels of $E$. coli when lettuce was stored at $4^{\circ} \mathrm{C}$ as compared to 10,22 , or $37^{\circ} \mathrm{C}$. In contrast, Gomez-Lopez et al. (2013) demonstrated that temperature differential and illumination conditions did not affect bacterial internalization into the plant. Furthermore, in this work, in contrast to the room temperature and light/dark storage condition, a combination of $4^{\circ} \mathrm{C}$ and darkness resulted in bacterial inactivation patterns similar to those obtained for 
$4^{\circ} \mathrm{C}$ and a light/dark photoperiod, with lower reductions achieved for $24 \mathrm{~h}$ biofilms than for $48 \mathrm{~h}$ biofilms, which confirms the effect of the temperature shift on bacterial survivability followed by treatment.

Air plasmas are excellent sources of ROS and RNS (Stoffels et al., 2008). Among the ROS, ozone, atomic oxygen, singlet oxygen, superoxide, peroxide, and hydroxyl radicals, are considered to contribute to the bacterial inactivation process (Joshi et al., 2011). In this work, high concentrations of ozone were recorded. Ozone is one of the long-lived reactive species, relevant to the effects of treatment that utilises post treatment storage and is expected to play an important role in antimicrobial efficacy of ACP. The DCFH-DA assay demonstrated generation of ROS inside L. monocytogenes and E.coli cells following treatment. However, concentrations of ROS were higher inside bacterial cells suspended in simpler media, such as PBS, by comparison with the concentrations of ROS recorded for cells treated in LB. The components of LB, such as proteins and vitamins, likely scavenged many of the plasma generated reactive species thus posing a protective effect against antimicrobial action of reactive species generated during the treatment. Furthermore, despite the thicker cell membrane, concentrations of ROS were higher inside cells of Gram- positive microorganism than inside cells of the Gram-negative. Han et al. (2014), comparing ACP antimicrobial efficacy between Gram-positive and Gram-negative bacteria, demonstrated that $L$. monocytogenes was more sensitive to ACP treatment than the two E. coli strains studied, attributed to a higher level of ROS penetrated inside Gram- positive than inside Gramnegative microorganism. However, the exact mechanisms of plasma mediated bacterial inactivation are not yet fully elucidated. One of the proposed mechanisms is the diffusion of ROS through the bacteria cell wall, causing local damage to the cytoplasmic membrane, protein and DNA strands, as well as physical effects causing microbial etching and erosion (Gallagher et al., 2007; Moreau et al., 2008). Our previous findings showed that the 
penetration ability of ACP generated species into bacterial suspensions was facilitated by 24 h of post-treatment storage (Ziuzina et al., 2013). As discussed by Shintani et al. (2010), the penetration depth of oxygen plasma generated species was predicted to be $<1,000 \mathrm{~nm}$ as estimated from the surface of spores. Furthermore, Pei et al. (2012) demonstrated that reactive plasma species produced a strong bactericidal effect penetrating through the layer of a $25.5 \mu \mathrm{m}$-thick Enterococcus faecalis biofilm. In this study, in order to investigate if ACP mediated reactive species could penetrate the internal layers of produce, SEM analysis of untreated and ACP treated Salmonella $48 \mathrm{~h}$ biofilms developed on lettuce at room temperature and light/dark photoperiod was conducted. It was evident that the selected storage conditions supported bacterial attachment, formation of biofilm aggregates and internalization within plant stomata, and that ACP treatment in conjunction with $24 \mathrm{~h}$ of post treatment storage had detrimental effects on unprotected bacteria, eliminating most of the cells from the surface of lettuce. However, inside stomata, where high concentrations of cells were noted and strong biofilm formation is anticipated, bacterial cells remained intact, suggesting that ACP generated reactive species could not penetrate colonized stomata through the complex biofilm matrices. This could explain the inability of the treatment to totally eliminate bacterial biofilms as demonstrated by the colony count assay. Similarly, Jahid et al. (2015) reported increased resistance of bacterial biofilms to plasma treatments due to internalization and extensive colonization in stomatal wells. It is also important to note that the majority, but not all lettuce stomata were found to be colonized before treatment, whereas higher proportions of stomata without colonization were observed on treated samples. However, the presence of some uncolonized stomata on untreated controls makes it difficult to holistically conclude about ACP decontamination efficacy against bacteria on the internal areas of plants. Although SEM analysis was conducted using bacterial biofilms developed under storage conditions chosen to enhance biofilm growth (room temperature), these results 
highlight the importance of informed effective microbiological control, as microorganisms protected by biofilms and/or the complex structures of different produce commodities may present major risks of cross-contamination of the environment in food production sites. Furthermore, internalization of bacteria in the internal natural cavities was promoted by the presence of light thereby significantly impacting ACP efficacy. Therefore, preventive measures such as maintenance of appropriate temperature regimes and minimised light exposure throughout the distribution chain remain extremely important factors for the assurance of microbiological safety of fresh produce in conjunction with novel approaches such as HVACP.

\section{Conclusion}

In summary, in-package high voltage indirect ACP treatment was very effective against planktonic populations of Salmonella, L. monocytogenes and E. coli, reducing high concentrations of bacterial cells $\left(\sim 7.0 \log _{10} \mathrm{CFU} / \mathrm{ml}\right)$ in lettuce broth within $30 \mathrm{~s}$ of treatment. However, extended treatment times of up to $300 \mathrm{~s}$ were required to attain substantial reductions for bacteria attached to lettuce surfaces $\left(2.4,2.3\right.$ and $3.3 \log _{10}$ CFU/sample for Salmonella, L. monocytogenes and E. coli, respectively). Furthermore, it has been shown that the storage conditions, such as temperature, light and time had interactive effects on bacterial proliferation and susceptibility to the ACP treatment. After $48 \mathrm{~h}$, bacterial biofilms developed on lettuce at room temperature in a light/dark photoperiod, exhibited higher resistance to ACP than $24 \mathrm{~h}$ biofilms. In contrast, biofilms developed at $4{ }^{\circ} \mathrm{C}$ in combination with either light storage condition during $48 \mathrm{~h}$ were more susceptible to the treatment than $24 \mathrm{~h}$ old biofilms. Overall, these results suggest that temperature and light conditions during produce distribution may promote bacterial internalisation and possible bacterial stress responses thereby significantly impacting the effectiveness of ACP and indeed other decontamination 
treatments. However, further research is needed, which will focus on the effects of pretreatment storage conditions in order to understand bacterial behaviour, adaptation to stress, development of cross protection and the corresponding response to ACP treatment in order to further optimise plasma treatment parameters for the consistent inactivation of pathogens on or in produce where enhanced produce quality characteristics are also attained.

\section{Acknowledgements}

The research leading to these results has received funding from the European Community's Seventh Framework Program (FP7/2207-2013) under grant agreement number 285820.

\section{References}

Abadias, M., Usall, J., Anguera, M., Solsona, C., Viñas, I., 2008. Microbiological quality of fresh, minimally-processed fruit and vegetables, and sprouts from retail establishments. International Journal of Food Microbiology 123, 121-129.

Al-Nabulsi, A.A., Osaili, T.M., Shaker, R.R., A.N. Olaimat., Jaradat, Z.W., Elabedeen, N.A.Z., Holley, R.A. 2015. Effects of osmotic pressure, acid, or cold stresses on antibiotic susceptibility of Listeria monocytogenes. Food Microbiology 46, $154-160$.

Alkawareek, M.Y., Algwari, Q.T., Graham, B., Gorman, S., O'Connell, D., Gilmore, B., 2012a. Application of atmospheric pressure nonthermal plasma for the in vitro eradication of bacterial biofilms. FEMS Immunology and Medical Microbiology 65, 381-384.

Alkawareek, M.Y., Algwari, Q.T., Laverty, G., Gorman, S.P., Graham, W.G., O’Connell, D., Gilmore, B.F., 2012b. Eradication of Pseudomonas aeruginosa biofilms by atmospheric pressure non-thermal plasma. PLoS ONE 7(8): e44289. doi:10.1371/journal.pone.0044289. 
Baier, M., Görgen, M., Ehlbeck, J., Knorr D., Herppich, W.B., Schlüter, O., 2014. Nonthermal atmospheric pressure plasma: Screening for gentle process conditions and antibacterial efficiency on perishable fresh produce. Innovative Food Science and Emerging Technologies 22, 147-157.

Barria, C., Malecki, M., Arraiano, C.M., 2013. Bacterial adaptation to cold. Microbiology $159,2437-2443$.

Beales, N., 2004. Adaptation of microorganisms to cold temperatures, weak acid preservatives, low $\mathrm{pH}$, and osmotic stress: A review. Comprehensive review in food science and food safety $3,1-20$.

Belessi, C.E.A., Gounadaki, A.S, Psomas, A.N., Skandamis, P.N., 2011. Efficiency of different sanitation methods on Listeria monocytogenes biofilms formed under various environmental conditions. International Journal of Food Microbiology 145, S46-S52.

Bett-Garber, K.L., Greene, J.L., Lamikanra, O., Ingram, D.A., Watson, M.A., 2011. Effect of storage temperature variations on sensory quality of fresh-cut cantaloupe melon. Journal of Food Quality 34, 19-29.

Buck, J. W., Walcott, R.R., Beuchat, L. R., 2003. Recent trends in microbiological safety of fruits and vegetables. Plant Health Progress, doi:10.1094/PHP-2003-0121-01-RV. Available at http://www.apsnet.org/ [Accessed on 12 November 2014].

Deering, A.J., Mauer, L.J., Pruitt, R.E., 2012. Internalization of E. coli O157:H7 and Salmonella spp. in plants: A review. Food Research International 45, 567-575. 
Delaquis, P., Bach, S., 2012. Resistance and sublethal damage. Produce contamination. In: Gomez-Lopez, V. M. (Ed.), Decontamination of Fresh and Minimally Processed Produce. Wiley-Blackwell Publishing, USA, pp. 77 - 89.

Fernandez, A., Noriega, E., Thompson, A., 2013. Inactivation of Salmonella enterica serovar Typhimurium on fresh produce by cold atmospheric gas plasma technology. Food Microbiology 33, $24-9$.

Gallagher, M.J. Jr., Vaze, N., Gangoli, S., Vasilets, V.N., Gutsol, A.F., Milovanova, T.N., Anandan, S., Murasko, D.M, Fridman A.A., 2007. Rapid inactivation of airborne bacteria using atmospheric pressure dielectric barrier grating gischarge. IEEE Transactions on plasma science $35,1501-1510$.

Giaouris, E., Heir, E., Hébraud, M., Chorianopoulos, N., Langsrud, S., Møretrø, T., Habimana, O., Desvaux, M., Renier, S., Nychas, G.-J., 2014. Attachment and biofilm formation by foodborne bacteria in meat processing environments: Causes, implications, role of bacterial interactions and control by alternative novel methods. Meat Science 97, 298-309.

Gil, M.I., Allende, A., 2012. Minimal processing. Produce contamination. In: Gomez-Lopez, V. M. (Ed.), Decontamination of Fresh and Minimally Processed Produce, Wiley-Blackwell Publishing, USA, pp. 105 - 116.

Golberg, D., Kroupitski, Y., Belausov, E., Pinto, R., Sela, S., 2011. Salmonella Typhimurium internalization is variable in leafy vegetables and fresh herbs. International Journal of Food Microbiology 145, 250-257. 
Gomez-Lopez, V.M., Marin, A., Allende, A., Beuchat, L., Gill, M.I., 2013. Postharvest handling conditions affect internalization of Salmonella in baby spinach during washing. Journal of Food protection 76, $1145-1151$.

Gu, G., Cevallos-Cevallos, J.M., Vallad, G.E., van Bruggen, A.H.C, 2013a. Organically managed soils reduce internal colonization of tomato plants by Salmonella enterica serovar Typhimurium. Phytopathology 103, $381-388$.

Gu, G., Cevallos-Cevallos, J.M., van Bruggen, A.H.C, 2013b. Ingress of Salmonella enterica Typhimurium into tomato leaves through hydathodes. PLoS ONE 8(1): e53470. doi:10.1371/journal.pone.0053470.

Han, L., Patil, S., Keener, K., Cullen, P. J., Bourke, P., 2014. Bacterial inactivation by High Voltage Atmospheric Cold Plasma: Influence of process parameters and effects on cell leakage and DNA. Journal of Applied Microbiology 116, 784-794.

Heard, G.M., 2002. Microbiology of fresh-cut produce. In: Lamikanra, O. (Ed.), Fresh-Cut Fruits and Vegetables. Science, Technology and Market. pp. 287 - 348.

Jahid, I.K., Han, N., Ha, S.-D., 2014a. Inactivation kinetics of cold oxygen plasma depend on incubation conditions of Aeromonas hydrophila biofilm on lettuce. Food Research International 55, 181-189.

Jahid, I.K., Han, N., Zhang, C.-Y., Ha, S.-D., 2015. Mixed culture biofilms of Salmonella Typhimurium and cultivable indigenous microorganisms on lettuce show enhanced resistance of their sessile cells to cold oxygen plasma. Food Microbiology 46, 383 - 394.

Jahid, I.K., Han, N.R., Srey, S., Ha, S.-D., 2014b. Competitive interactions inside mixedculture biofilms of Salmonella Typhimurium and cultivable indigenous microorganisms on 
lettuce enhance microbial resistance of their sessile cells to ultraviolet $\mathrm{C}$ (UV-C) irradiation. Food Research International 55, 445-454.

Joshi, S. G., Cooper, M., Yost, A., Paff, M., Ercan, U. K., Fridman, G., Fridman, G., Fridman, A., Brooks, A. D., 2011. Nonthermal dielectric-barrier discharge plasma-induced inactivation involves oxidative DNA damage and membrane lipid peroxidation in Escherichia coli. Antimicrobial Agents and Chemotherapy 55, 1053 - 1062.

Kim, S.-H., Wei C., 2012. Biofilms. In: Gomez-Lopez, V. M. (Ed.), Decontamination of Fresh and Minimally Processed Produce, Wiley-Blackwell Publishing, USA, pp. 59-71.

Koseki, S., Isobe, S., 2005. Growth of Listeria monocytogenes on iceberg lettuce and solid media. International Journal of Food Microbiology 101, 217-225.

Kroupitski, Y., Golberg, d., Belausov, E., Pinto, R., Swartzberg, D., Granot, D., Sela, S., 2009. Internalization of Salmonella enterica in leaves is induced by light and involves chemotaxis and penetration through open stomata. Applied and Environmental Microbiology $75,6076-6086$.

Kvam, E., Davis, B., Mondello, F., Garner, A.L., 2012. Nonthermal atmospheric plasma rapidly disinfects multidrug-resistant microbes by inducing cell surface damage. Antimicrobial Agents and Chemotherapy 57, 2028-2036.

Lacombe, A., Niemira, B.A., Gurtler, G.B., Fan, X., Sites, J., Boyd, G., Chen, H., 2015. Atmospheric cold plasma inactivation of aerobic microorganisms on blueberries and effects on quality attributes. Food Microbiology 46, 479-484.

Lehto, M., Kuisma, R., Määttä, J., Kymäläinenb, H-R., Mäki, M., 2011. Hygienic level and surface contamination in fresh-cut vegetable production plants. Food Control 22, 469-475. 
Mahmoud, B.S.M., 2010. The effects of X-ray radiation on Escherichia coli O157:H7, Listeria monocytogenes, Salmonella enterica and Shigella flexneri inoculated on whole Roma tomatoes. Food Microbiology 27, 1057-1063.

Maisch, T., Shimizu, T., Isbary, G., Heinlin, J., Karrer, S., Klämpfl, T.G., Li, Y.F., Morfill, G., Zimmermann, J.L., 2012. Contact-free inactivation of Candida albicans biofilms by cold atmospheric air plasma. Applied and Environmental Microbiology 78, 4242-4247.

Martinez-Sanchez, A., Tudela, J.A., Luna, C., Allende, A., Gil, M.I., 2011. Low oxygen levels and light exposure affect quality of fresh-cut Romaine lettuce. Postharvest Biology and Technology 59, 34-42.

Misra, N.N., Patil, S., Moiseev, T., Bourke, P., Mosnier, J.P., Keener, K.M., Cullen, P.J., 2014. In-package atmospheric pressure cold plasma treatment of strawberries. Journal of Food Engineering 125, 131-138.

Moiseev, T., Misra, N., Patil, S., Cullen, P., Bourke, P., Keener, K., Mosnier, J.-P., 2014. Post-discharge gas composition of a large-gap DBD in humid air by UV-Vis absorption spectroscopy. Plasma Sources Science and Technology 23, 1-13.

Moreau, M., Orange, N., Feuilloley, M. G. J., 2008. Non-thermal plasma technologies: New tools for bio-decontamination. Biotechnology Advances 26, 610-617.

O’Beirne, D., Gleeson, E., Auty, M., Jordan, K., 2014. Effects of processing and storage variables on penetration and survival of Escherichia coli $\mathrm{O} 157: \mathrm{H} 7$ in fresh-cut packaged carrots. Food Control 40, $71-77$.

Olaimat, A.N., Holley R.A., 2012. Factors influencing the microbial safety of fresh produce: A review. Food Microbiology 32, $1-19$. 
Olmez, H., Temur, S.D., 2010. Effects of different sanitizing treatments on biofilms and attachment of Escherichia coli and Listeria monocytogenes on green leaf lettuce. LWT Food Science and Technology 43, 964-970.

Pei, X., Lu, X., Liu, J., Liu, D., Yang, Y., Ostrikov, K., Chu, P.K., Pan, Y., 2012. Inactivation of a $25.5 \mu \mathrm{m}$ Enterococcus faecalis biofilm by a room-temperature, batteryoperated, handheld air plasma jet. Journal of Physics D: Applied Physics 45, 165205, 1 - 5.

Shen, C., Luo, Y., Nou, X., Bauchan, G., Zhou, B., Wang, Q., Millner, P., 2012. Enhanced inactivation of Salmonella and Pseudomonas biofilms on stainless steel by use of T-128, a fresh-produce washing aid, in chlorinated wash solutions. Applied and Environmental Microbiology 78, 6789-6798.

Shen, Y., Stojicic, S., Haapasalo, M., 2011. Antimicrobial efficacy of chlorhexidine against bacteria in biofilms at different stages of development. Journal of Endodontics 37, 657-661.

Shintani, H., Sakudo, A., Burke, P., McDonnell, G., 2010. Gas plasma sterilization of microorganisms and mechanisms of action (Review). Experimental and Therapeutic Medicine 1, 731-738.

Solomon, E.B., Sharma, M., 2009. Microbial attachment and limitations of decontamination methodologies. In: Sapers, G.M., Solomon, E.B., Matthews, K.R. (Ed.), The produce contamination problem: Causes and solutions. Elsevier Inc., USA, pp. $21-45$.

Srey, S., Park, S.Y., Jahid, I.K., Ha, S-D. (2014). Reduction effect of the selected chemical and physical treatments to reduce L. monocytogenes biofilms formed on lettuce and cabbage. Food Research International 62, 484-491. 
Stoffels, E., Sakiyama, Y., Graves, D.B., 2008. Cold atmospheric plasma: charged species and their interactions with cells and tissues. IEEE Transactions on plasma science 36, 1441 1457.

Sun, Y., Yu, S., Sun, P., Wu, H., Zhu, W., Liu, W., Zhang, J., Fang, J., Li, R., 2012.

Inactivation of Candida biofilms by non-thermal plasma and its enhancement for fungistatic effect of antifungal drugs. PLoS ONE 7(7): e40629. doi:10.1371/journal.pone.004062

Takeuchi, K., Hassan, A.N., Frank, J.F., 2001. Penetration of Escherichia coli O157:H7 into lettuce as influenced by modified atmosphere and packaging. Journal of Food Protection 11, $1820-1824$.

Traba, C., Chen, L., Liang, J.F., 2013. Low power gas discharge plasma mediated inactivation and removal of biofilms formed on biomaterials. Current Applied Physics 13, S12-S18

Traba, C., Liang, J.F., 2011. Susceptibility of Staphylococcus aureus biofilms to reactive discharge gases. Biofouling 27, 763-772. doi:10.1080/08927014.2011.602188.

Van Boxstael, S., Habib, I., Jacxsens, L., De Vocht, M., Baert, L., Van De Perre, E., Rajkovic, A., Lopez-Galvez, F., Sampers, I., Spanoghe, P., De Meulenaer, B., Uyttendaele, M., 2013. Food safety issues in fresh produce: Bacterial pathogens, viruses and pesticide residues indicated as major concerns by stakeholders in the fresh produce chain. Food Control 32, 190-197.

Warning, A., Datta, A.K., 2013. Interdisciplinary engineering approaches to study how pathogenic bacteria interact with fresh produce. Journal of Food Engineering 114, 426-448. 
Zhan, L., Hu, J., Li, Y., Pang, L., 2012. Combination of light exposure and low temperature in preserving quality and extending shelf-life of fresh-cut broccoli (Brassica oleracea L.). Postharvest Biology and Technology 72, 76-81.

Ziuzina, D., Patil, S., Cullen, P.J., Keener, K.M., Bourke, P., 2014. Atmospheric cold plasma inactivation of Escherichia coli, Salmonella enterica serovar Typhimurium and Listeria monocytogenes inoculated on fresh produce. Food Microbiology 42, 109-116.

Ziuzina, D., Patil, S., Cullen, P.J., Keener, K.M., Bourke, P., 2013. Atmospheric cold plasma inactivation of Escherichia coli in liquid media inside a sealed package. Journal of applied microbiology 114, 778-787.

\section{Figure legends}

Fig. 1. Effect of ACP treatment ( $30 \mathrm{~s})$ and post treatment storage time $\left(24 \mathrm{~h}\right.$ at $\left.4^{\circ} \mathrm{C}\right)$ on Salmonella (St), L. monocytogenes (Lm) and E. coli (Ec) in lettuce broth (3\%): (回) inoculated control and $(\mathbf{\nabla})$ ACP treated samples. ND: not detectable; limit of detection 1.0 $\log _{10} \mathrm{CFU} / \mathrm{ml}$. Vertical bars represent standard deviation.

Fig. 2. Effect of ACP treatment (300 s) and post treatment storage time ( $24 \mathrm{~h}$ at $\left.4^{\circ} \mathrm{C}\right)$ on Salmonella $(\mathrm{St})$, L. monocytogenes $(\mathrm{Lm})$ and E. coli $(\mathrm{Ec})$ inoculated on lettuce: (圆) untreated control and (\$) ACP treated samples. Columns with different letters indicate a significant difference between the bacterial levels $(\mathrm{p}<0.05)$. Vertical bars represent standard deviation.

Fig. 3. Effect of ACP treatment (300 s) and post treatment storage time $\left(24 \mathrm{~h}\right.$ at $\left.4^{\circ} \mathrm{C}\right)$ on Salmonella $(\mathrm{St})$, L. monocytogenes $(\mathrm{Lm})$ and E. coli $(\mathrm{Ec})$ biofilms formed on lettuce at room temperature in light/dark photoperiod: (國) untreated control, ACP treated $24 \mathrm{~h}(\boldsymbol{\nabla})$ and $48 \mathrm{~h}$ 
$(\boldsymbol{\square})$ biofilms. Columns with different letters indicate a significant difference between the bacterial levels $(\mathrm{p}<0.05)$. Vertical bars represent standard deviation.

Fig. 4. Effect of ACP treatment (300 s) and post treatment storage time ( $24 \mathrm{~h}$ at $\left.4^{\circ} \mathrm{C}\right)$ on Salmonella (St), L. monocytogenes (Lm) and E. coli (Ec) biofilms formed on lettuce at $4^{\circ} \mathrm{C}$ in light/dark photoperiod: (佪) untreated control, ACP treated $24 \mathrm{~h}(\boldsymbol{\nabla})$ and $48 \mathrm{~h}(\boldsymbol{\Xi})$ biofilms. Columns with different letters indicate a significant difference between the bacterial levels $(\mathrm{p}<0.05)$. Vertical bars represent standard deviation.

Fig. 5. Effect of ACP treatment (300 s) and post treatment storage time ( $24 \mathrm{~h}$ at $\left.4{ }^{\circ} \mathrm{C}\right)$ on Salmonella $(\mathrm{St})$, L. monocytogenes $(\mathrm{Lm})$ and $E$. coli $(\mathrm{Ec})$ biofilms formed on lettuce at $4{ }^{\circ} \mathrm{C}$ in dark: (回) untreated control, ACP treated $24 \mathrm{~h}(\boldsymbol{\nabla})$ and $48 \mathrm{~h}(\boldsymbol{\Xi})$ biofilms. Columns with different letters indicate a significant difference between the bacterial levels $(\mathrm{p}<0.05)$. Vertical bars represent standard deviation.

Fig. 6. CLSM images of E. coli XL10 (GFP) $24 \mathrm{~h}$ biofilms formed on lettuce at (a) room temperature in light/dark, (b) $4^{\circ} \mathrm{C}$ in light/dark and (c) $4^{\circ} \mathrm{C}$ in dark. Arrows indicate localisation of cells.

Fig. 7. SEM images of Salmonella $48 \mathrm{~h}$ biofilms formed on lettuce at room temperature and light/dark photoperiod: (a) untreated control and (b) ACP treated sample. Black arrows indicate intact bacterial cells and red arrows indicate cell debris.

Fig. 8. Concentration of ROS generated after $30 \mathrm{~s}$ of indirect ACP treatment inside Listeria

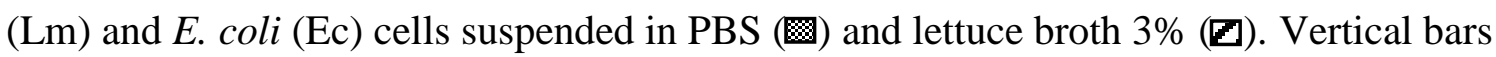
represent standard deviation. 
Figures

Figure 1:

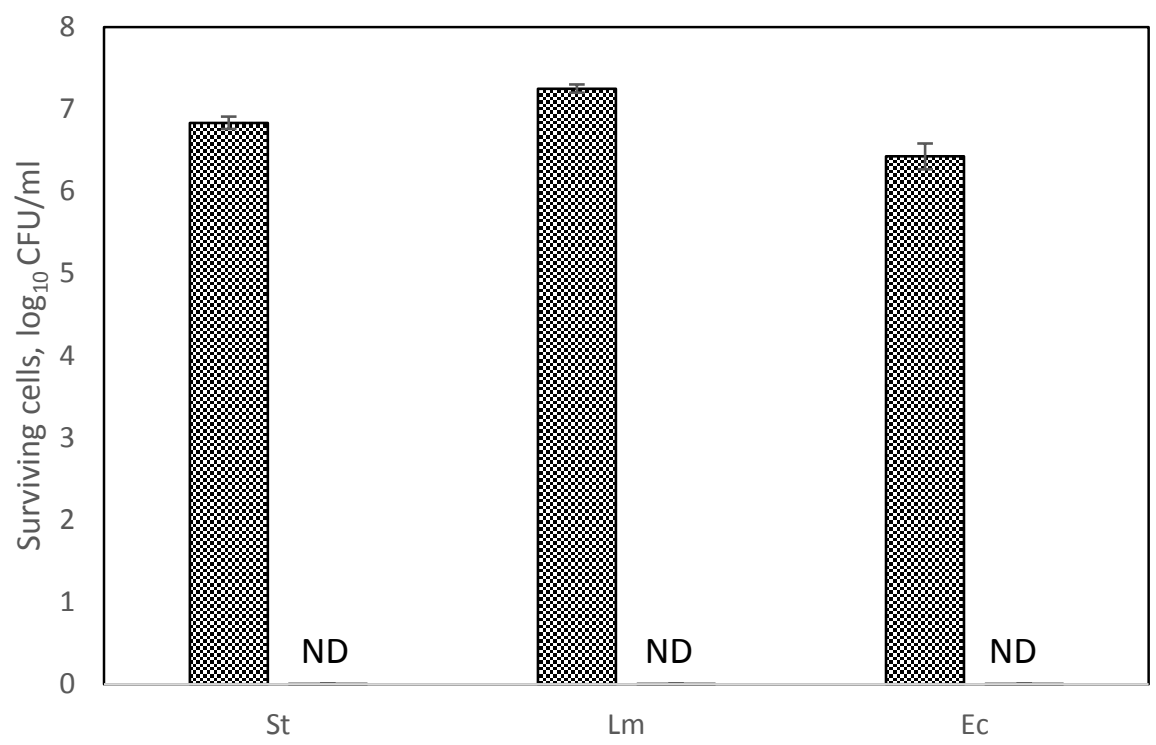

Figure 2:

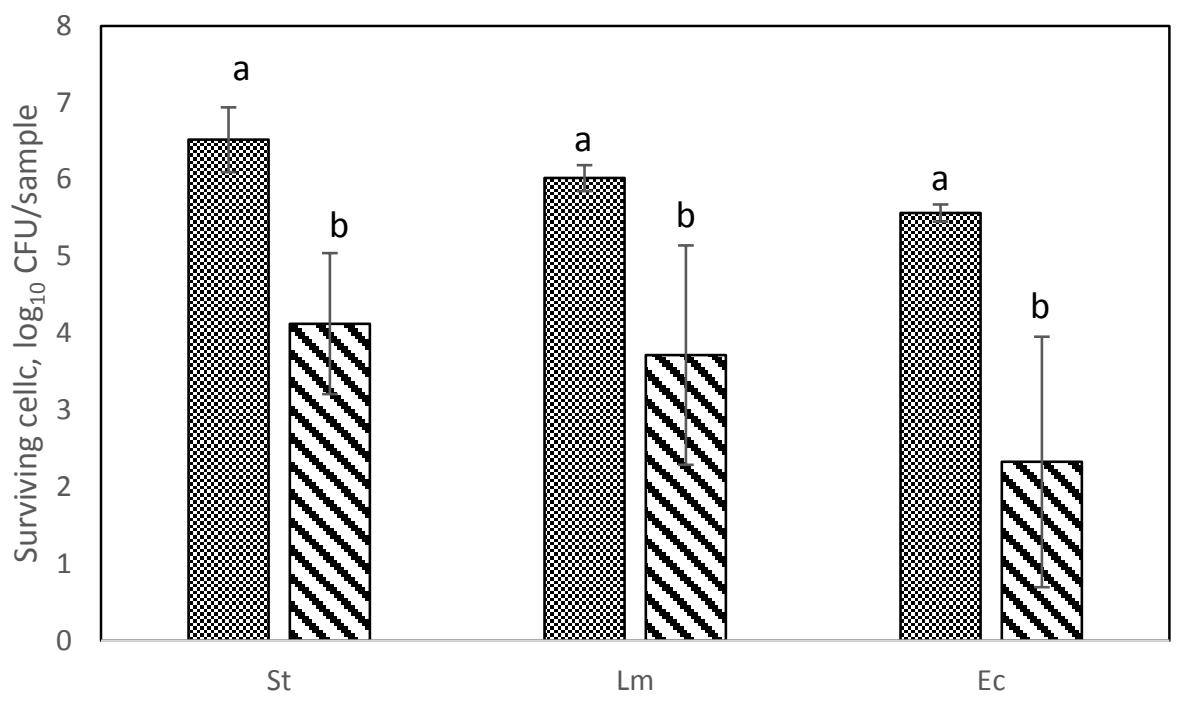


Figure 3:

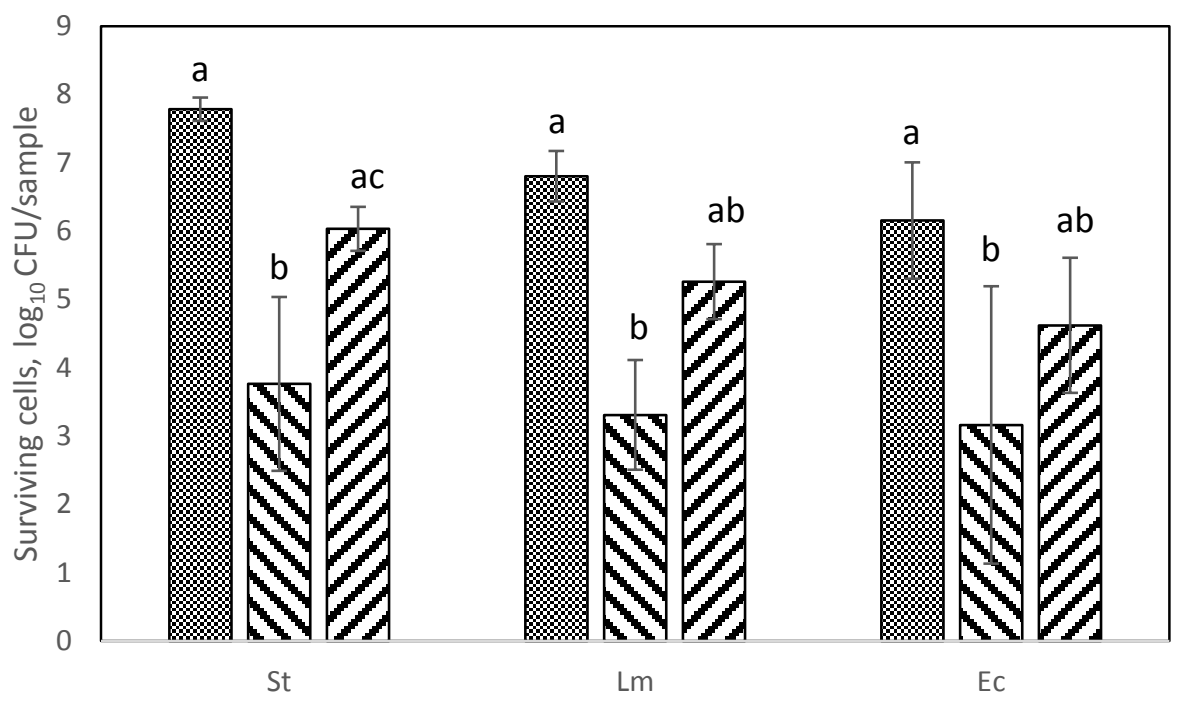

Figure 4:

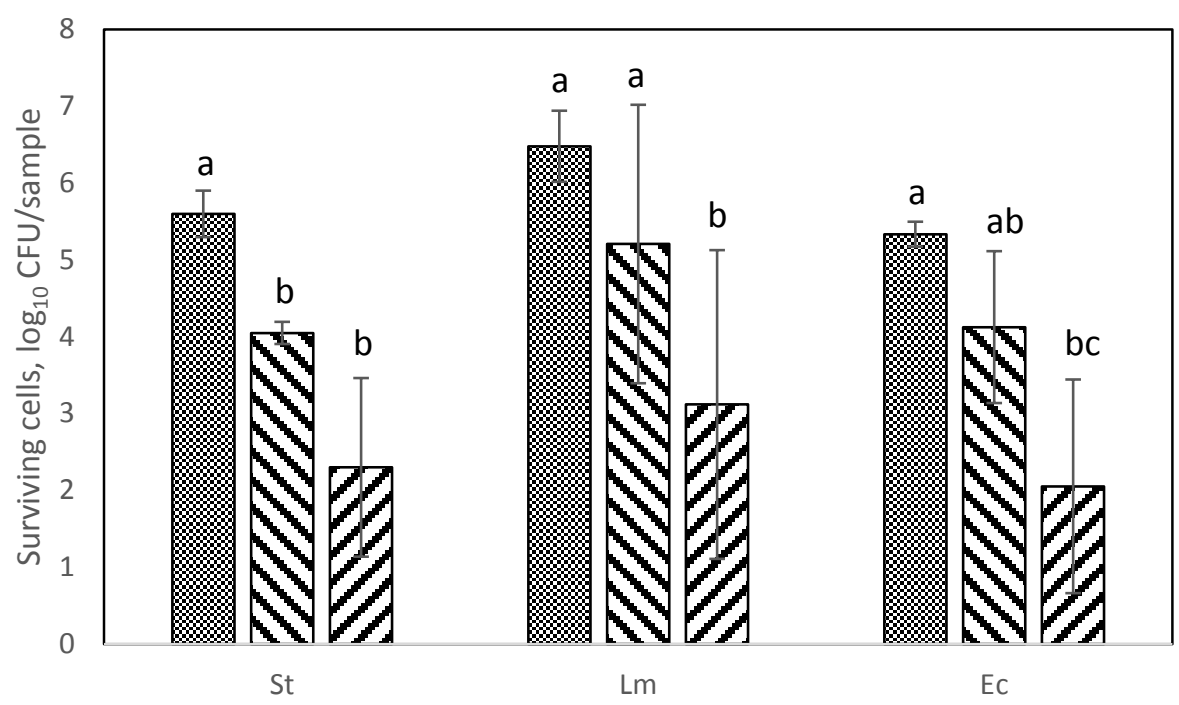


Figure 5:

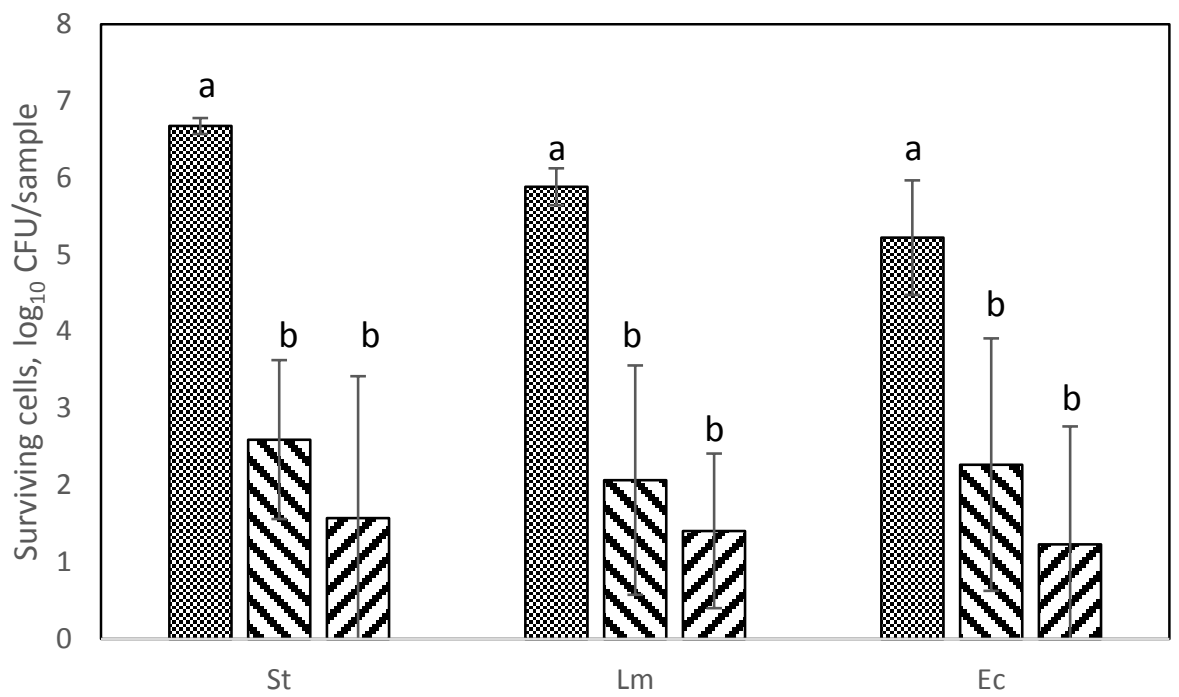

Figure 6:

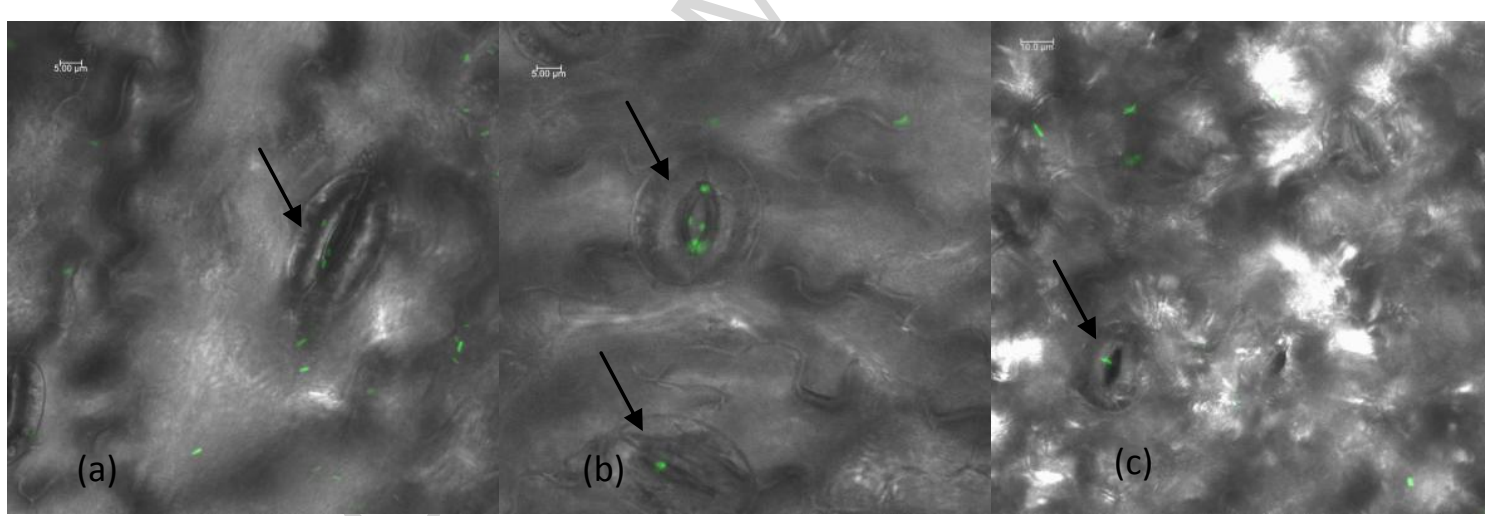


Figure 7:
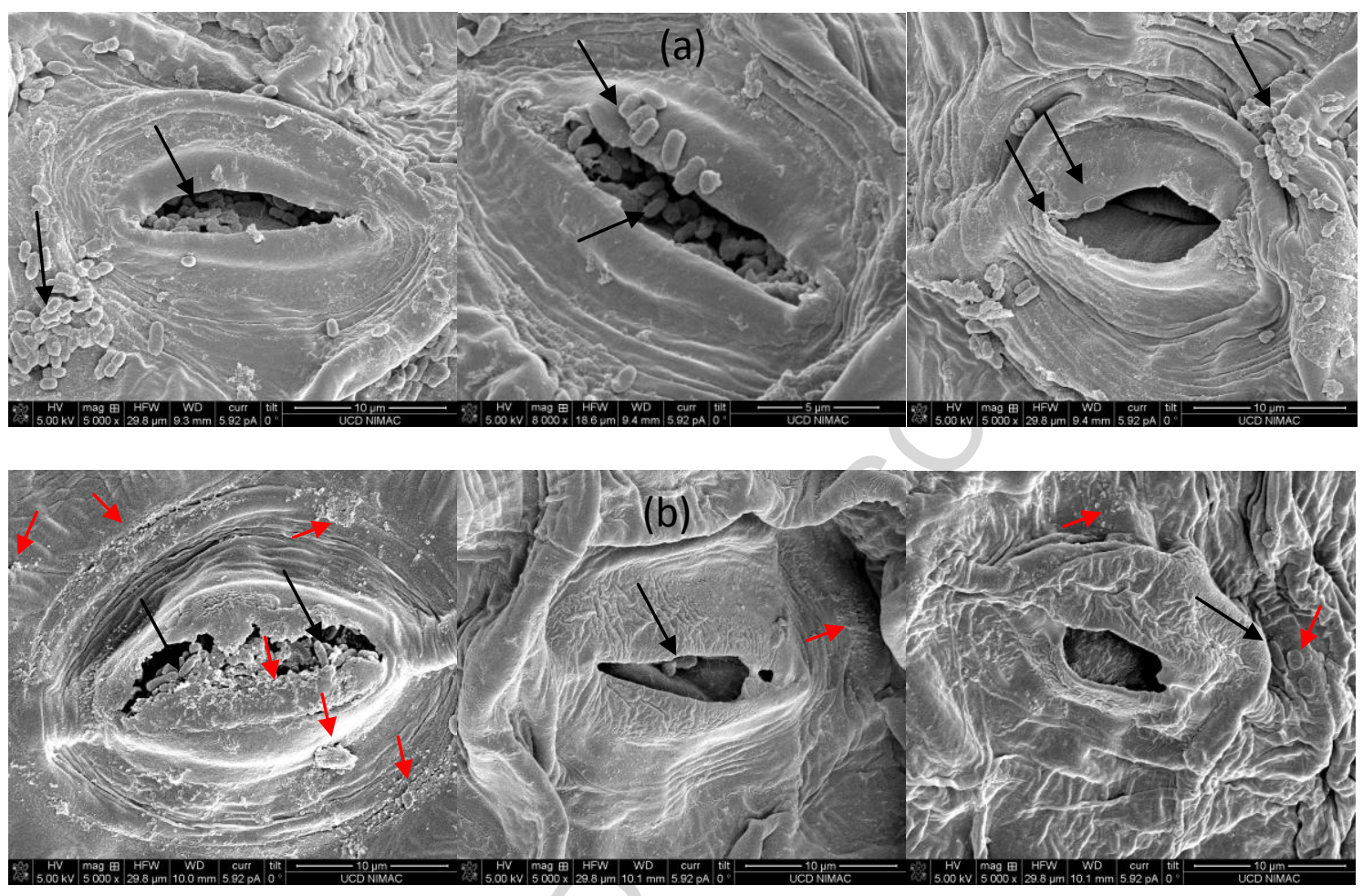

Figure 8:

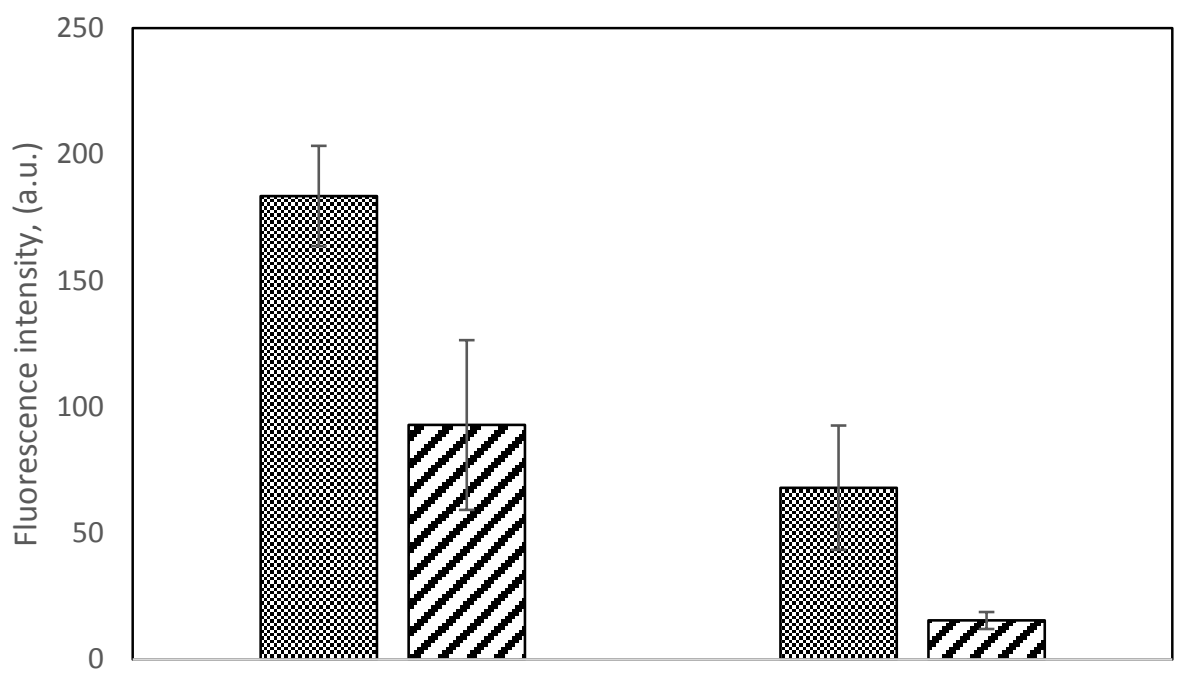

Lm

Ec 
Cold plasma inactivation of internalised bacteria and biofilms for Salmonella enterica serovar Typhimurium, Listeria monocytogenes and Escherichia coli

Highlights:

- High voltage in-package ACP treatment for 30s reduced bacterial populations in lettuce broth by $7 \log _{10} \mathrm{CFU} / \mathrm{ml}$

- Extended ACP treatment (300s) effectively reduced biofilm populations on lettuce $(<5$ $\log 10 \mathrm{CFU} / \mathrm{ml})$

- Inactivation on lettuce was affected by age of bacterial biofilm and storage conditions of light and temperature)

- ACP technology in combination with appropriate storage conditions has the potential to overcome bacterial challenges associated with fresh produce 